Notes

\title{
RATIONAL EXPECTATIONS OF LENIENCY: IMPLICIT PLEA AGREEMENTS AND THE PROSECUTOR'S ROLE AS A MINISTER OF JUSTICE
}

\author{
ELI PAUL MAZUR
}

\section{INTRODUCTION}

Prosecutors routinely acquire the incriminating testimony of codefendants, co-conspirators, informants, jailhouse snitches, and witnesses through the use of plea bargains and inducements. ${ }^{1}$ The Supreme Court has explicitly recognized that plea bargains and inducements create motivations to lie. ${ }^{2}$ Nevertheless, the function and history of the plea bargain is ingrained in our system of justice, and courts consistently hold that the existent procedural safeguards are sufficiently stringent to protect the accused from any unfair prejudice created by bargained-for testimony. ${ }^{3}$

The accused is protected by various procedural mechanisms that expose the existence of bargained-for testimony and allow the accused to attack its credibility. ${ }^{4}$ The negotiation, creation, and performance of plea agreements and inducements are governed by rules

Copyright (C) 2002 by Eli Paul Mazur.

1. See, e.g., Marcus Dirk Dubber, American Plea Bargains, German Lay Judges, and the Crisis of Criminal Procedure, 49 STAN. L. REV. 547, 592 (1997) (stating that "plea bargains dispose of approximately 90 percent of criminal cases").

2. See Hoffa v. United States, 385 U.S. 293, 311 (1966) (recognizing the inherent motivation to lie created by bargained-for testimony); see also, e.g., United States v. CervantesPacheco, 826 F.2d 310, 315 (5th Cir. 1987) ("It is difficult to imagine a greater motivation to lie than the inducement of a reduced sentence ....").

3. For the purposes of this Note, this position is acceptable. See, e.g., Hoffa, 385 U.S. at 311 ("The established [procedural] safeguards of the Anglo-American legal system leave the veracity of a witness to be tested by cross-examination, and the credibility of his testimony to be determined by a properly instructed jury.").

4. See infra notes $128-41$ and accompanying text. 
of criminal procedure and informed by rules of professional conduct. ${ }^{5}$ For instance, a plea bargain between the state and a testifying witness is discoverable, ${ }^{6}$ many plea bargains are written, and the prosecution has an ethical and legal duty to disclose the agreement for its exculpatory value. ${ }^{7}$ Moreover, all plea agreements are subject to the scrutiny of a properly instructed jury and zealous cross-examination by defense counsel. ${ }^{8}$ These procedural safeguards exist to promote justice and accuracy in the courtroom. ${ }^{9}$ They recognize that when a prosecutor offers leniency or money in exchange for incriminating testimony, there is a tremendous incentive for the witness to fabricate, selfexculpate, and cooperate. ${ }^{10}$

However, these safeguards fail to protect the rights of the accused and the integrity of the court when a witness cooperates with the prosecution but is not a party to a formal plea agreement. Through affirmative behavior, office policy, or a past course of conduct, a prosecutor can create a "rational expectation of leniency"11

5. See generally FED. R. CRIM. P. 11 (regulating the making of plea agreements); MODEL RULES OF PROF'L CONDUCT R. 3.8(d) (1997) (noting that the prosecutor shall "make timely disclosure to the defense of all evidence or information known to the prosecutor that tends to negate the guilt of the accused or mitigates the offense").

6. See FED. R. CRIM. P. 11(e) (specifying the plea agreement procedure).

7. See Giglio v. United States, 405 U.S. 150, 153-54 (1972) (holding that the prosecution's failure to disclose a plea bargain with a testifying codefendant warranted a new trial because evidence questioning the credibility of a key prosecution witness is exculpatory in nature and nondisclosure constitutes a Brady violation); see also Brady v. Maryland, 373 U.S. 83, 87 (1963) ("The suppression by the prosecution of evidence favorable to an accused upon request violates due process where the evidence is material either to guilt or to punishment, irrespective of the good faith or bad faith of the prosecution."); Napue v. Illinois, 360 U.S. 264, 269 (1959) ("The jury's estimate of the truthfulness and reliability of a given witness may well be determinative of guilt or innocence, and it is upon such subtle factors as the possible interest of the witness in testifying falsely that a defendant's life or liberty may depend."); MODEL RULES OF PROF'L CONDUCT R. 3.8(d) (1997) (taking a more expansive view than the Supreme Court or the Federal Rules of Criminal Procedure of the prosecutor's duty to disclose exculpatory evidence by requiring "disclosure ... of all evidence or information known to the prosecutor that tends to negate" guilt or mitigate the sentence of the accused).

8. Hoffa, 385 U.S. at 311.

9. See FED. R. EVID. 102 ("These rules shall be construed to secure fairness ... to the end that the truth may be ascertained and proceedings justly determined."); FED. R. CRIM. P. 2 ("These rules are intended to provide for the just determination of every criminal proceeding. They shall be construed to secure ... fairness in administration ....").

10. United States v. Cervantes-Pacheco, 826 F.2d 310, 315 (5th Cir. 1987).

11. For purposes of this Note, a "rational expectation of leniency" results when a reasonable witness would believe—based on a prosecutor's affirmative conduct, office policy, or prior course of conduct - that he can minimize his punishment by providing the testimony the prosecutor desires. However, it should be noted that rational expectations of a benefit, such as the 
within the mind of a testifying witness. This rational expectation of leniency spawns the same dangers to the veracity of testimony and the credibility of witnesses as do traditional plea bargains. ${ }^{12}$

The stringent procedural safeguards governing plea bargains, however, are relaxed and rendered ineffective when the prosecution and the testifying witness do not reach a formal agreement. ${ }^{13}$ Crossexamination and jury instructions, as presently used, fail to apprise the jury of the equally pervasive motivations to fabricate and selfexculpate possessed by witnesses who testify with a rational expectation of leniency instead of a formal plea agreement. ${ }^{14}$

Experience and social science suggest that a witness's propensity to fabricate is just as compelling whether he has a rational expectation of leniency or a formal agreement promising leniency. ${ }^{15}$ The witness who testifies without a formal agreement is acutely aware of the heightened importance of the substance, power, and incriminating nature of his or her testimony, because his or her liberty might be contingent on the success or failure of the prosecution's case. In addition, jurors often give more weight and credibility to accomplice testimony where no formal plea agreement exists, because the testifying accomplice appears to waive his or her right against self-incrimination and to testify out of a desire for absolution and repentance. ${ }^{16}$ Therefore, courts and prosecutors should recognize that the dangers posed by traditional plea bargains are equally pervasive when a witness has a rational expectation of leniency attributable to the prosecution. ${ }^{17}$

This Note shows that rational expectations of leniency implicate the same doubts about the veracity of testimony as traditional plea bargains. Furthermore, it argues that prosecutors, as ministers of justice entrusted to protect the procedural rights of the accused ${ }^{18}$ violate

payment of money, also could influence witness testimony. Throughout this Note, I will use the phrase "rational expectation of leniency" to convey both concepts.

12. See infra note 144 and accompanying text.

13. See infra notes $151-71$ and accompanying text.

14. See infra notes $151-71$ and accompanying text.

15. See infra note 147 and accompanying text.

16. See Williamson v. United States, 512 U.S. 594, 599-600 (1994) (implying, in an opinion by Justice O'Connor, that a codefendant's testimony, when the codefendant has not executed a plea bargain, has enhanced credibility because "[o]ne of the most effective ways to lie is to mix falsehood with truth, especially truth that seems particularly persuasive because of its selfinculpatory nature").

17. See infra Part IV.A.

18. See Model Rules of Prof'L Conduct R. $3.8 \mathrm{cmt}$. (1997) (“A prosecutor has the responsibility of a minister of justice and not simply that of an advocate. This responsibility carries 
their ethical duties when they engage in implicit plea bargaining because such conduct circumvents and renders ineffective the procedural safeguards erected to protect the accused.

In Part I, I describe three situations in which prosecutors routinely create rational expectations of leniency in the minds of testifying witnesses without using formal plea agreements. I also describe the case law on the issue of informal plea agreements. In Part II, I explore the jurisprudence of the traditional plea bargain. The academic literature surrounding the Singleton ${ }^{19}$ and Williamson ${ }^{20}$ cases articulates the two dangers institutionalized plea bargains pose to the administration of justice. In Part III, I demonstrate how courts have constructed procedural safeguards to ensure the rights of the accused.

In Part IV, I explore how and why a witness's rational expectation of leniency implicates the same dangers to the administration of justice as the institutionalized plea bargain. I consider the relevant social science research into the effects of a witness's rational expectation of leniency. Research shows that witnesses are more likely to lie, more likely to cooperate, and more likely to fabricate when agents of the state make implicit rather than explicit promises of leniency. Moreover, the procedural safeguards erected to protect the accused from the dangers of the institutionalized plea agreement are ineffective when a witness merely has a rational expectation of leniency.

In Part V, I propose two solutions to mitigate the problems posed by rational expectations of leniency. First, I propose that, for the purposes of cross-examination, confrontation, and jury instructions, courts should not differentiate between witnesses who testify against the accused under a formal agreement or under a rational expectation of leniency. Second, I propose that prosecutors should explicitly recognize the ethical implications created by the implicit plea bargain and rational expectations of leniency: prosecutors' creating rational expectations of leniency in exchange for testimony violates ethical, legal, constitutional, and moral standards of conduct. As established by the American Bar Association Code of Professional Conduct, the prosecutor, as a minister of justice and not solely an advocate, has a duty to eliminate the practice of making implicit plea bargains.

with it specific obligations to see that the defendant is accorded procedural justice ....").

19. United States v. Singleton, 144 F.3d 1343 (10th Cir. 1998) [hereinafter Singleton I]; United States v. Singleton, 165 F.3d 1297 (10th Cir. 1999) [hereinafter Singleton II].

20. Williamson v. United States, 512 U.S. 594 (1994). 


\section{JUDICIAL RESPONSE TO RATIONAL EXPECTATIONS OF LENIENCY}

The United States Supreme Court held in Brady v. Maryland ${ }^{21}$ that the prosecution is required to disclose all exculpatory evidence to the accused. ${ }^{22}$ The Court held in Giglio v. United States ${ }^{23}$ that the prosecution's failure to disclose a formal plea bargain with a testifying witness constitutes a Brady violation because the existence of the plea bargain calls into question the credibility of a key prosecution witness and therefore is exculpatory. ${ }^{24}$ In Giglio, the defendant had "smoking gun" evidence of the prosecution's undisclosed, formal oral agreement with the witness; a government affidavit confirmed that an assistant district attorney made an overt promise not to prosecute the cooperating witness. ${ }^{25}$ However, in many cases the defendant is unable to obtain such good evidence. Rather, the defendant must rely on persuasive circumstantial evidence that the prosecution conveyed a promise, agreement, or rational expectation of leniency overtly or covertly to a cooperating witness. ${ }^{26}$ For example, the fact that the prosecution permitted a co-conspirator who testified against the defendant to plead guilty to a lesser offense might constitute evidence that an implicit agreement existed. ${ }^{27}$

A defendant might show that the prosecution created a rational expectation of leniency in the mind of a testifying witness in any of three ways. First, the defendant might allege that the prosecutor created such an expectation through affirmative conduct. ${ }^{28}$ Second, the defendant might allege that the prosecutor's office had an unofficial "office policy" of charging cooperating witnesses with lesser offenses. ${ }^{29}$ Third, the defendant might allege that the prosecutor's past course of conduct, over a substantial period of time, gave the cooperating witness, and his or her attorney, a rational expectation of leni-

\footnotetext{
21. 373 U.S. 83 (1963).

22. Id. at 87.

23. 405 U.S. 150 (1972).

24. Id. at $153-54$.

25. Id. at 152 .

26. See infra notes $28-30$ and accompanying text.

27. See, e.g., United States v. Ramirez, 608 F.2d 1261, 1266 (9th Cir. 1979) (holding that the fact that the witness for the government pled guilty to a lesser offense three days after trial was not enough to establish the existence of an agreement); Haire v. State, 8 S.W.3d 468, 472 (Ark. 2000) ("The mere fact, standing alone, that the charges [against the co-conspirator] were dropped after the trial does not establish a Giglio violation.").

28. E.g., Zuern v. Tate, 101 F. Supp. 2d 948, 971 (S.D. Ohio 2000).

29. E.g., Darden v. United States, 405 F.2d 1054, 1056 (9th Cir. 1969).
} 
ency in exchange for cooperation. ${ }^{30}$ In this Part, I show how courts have disposed of these three types of claims.

\section{A. Affirmative Conduct of a Prosecutor}

In Zuern v. Tate, William Zuern was convicted and sentenced to death for murdering a prison guard. ${ }^{31}$ After exhausting his state court remedies, Zuern filed a writ of habeas corpus in federal court arguing that his conviction violated several provisions of the Constitution. ${ }^{32}$ In particular, Zuern argued that the prosecution, in violation of Brady ${ }^{33}$

30. Most commonly, a prosecutor's past course of conduct will create the rational expectation of leniency. A myriad of cases highlight this problem and demonstrate the method that courts utilize to dispose of these claims. See, e.g., Gilday v. Callahan, 59 F.3d 257, 268-70 (1st Cir. 1995) (refusing to grant a new trial where two prosecution witnesses denied the existence of a deal); Mastrian v. McManus, 554 F.2d 813, 822-24 (8th Cir. 1977) (holding that newly discovered evidence relating to promises of leniency made by the prosecution to incriminating witnesses was not credible); United States ex rel. Fazio v. Fay, 348 F.2d 418, 420 (2d Cir. 1965) (holding that testimony was not perjured or false where defense counsel only questioned the incriminating witness on his subjective expectations of receiving leniency in exchange for testimony); United States v. Pheribo, 346 F.2d 559, 560-61 (2d Cir. 1965) (holding that a witness's expectations of leniency were sufficiently exposed by zealous cross-examination); Zuern, $101 \mathrm{~F}$. Supp. 2d at 970-72 (holding that a witness's expectation of leniency, even if proved, does not implicate Brady because no explicit agreement existed between the state and the witness); Brown v. Keane, No. 97-C3302, 1999 U.S. Dist. LEXIS 9615, at *9_*13 (S.D.N.Y. June 28, 1999) (holding that no tacit agreement existed where the prosecutor notified the parole board of the witness's cooperative testimony); Johnston v. Love, No. 94-3727, 1995 U.S. Dist. LEXIS 21426, at *30-*35 \& n.6 (E.D. Pa. Oct. 18, 1995) (holding that Brady did not require the prosecution to disclose the witness's expectation of leniency when the witness's lawyer stated that he knew through "experience" that his client would benefit from giving incriminating testimony); Barrett v. United States, 763 F. Supp 658, 656-61 \& nn.2-3 (D. Me. 1991) (holding that "[d]espite Petitioner's assertion that no other scenario can be imagined than an expectation of leniency, .... the Court can readily 'imagine' that [the witness] expected nothing . . . other than a break from the tedium of imprisonment"); Voyles v. Watkins, 489 F. Supp 901, 906 (N.D. Miss. 1980) (holding that an individual "voluntarily became a witness for the state in the hope and expectation that leniency might be shown him, but no agreement, understanding or deal of any sort, either express or implied, was made by the prosecution to secure his testimony"); Garcia v. State, 711 S.W.2d 176, 177-78 (Ark. Ct. App. 1986) (upholding a defendant's conviction when a codefendant testified that he did expect leniency but that his sole purpose in testifying was to "tell the truth"); People v. Phillips, 711 P.2d 423, 432-34 (Cal. 1985) (holding that reversal was not required where a witness testified with an expectation of leniency based on his attorney's advice to have "'faith and trust' in her (the attorney) and testify" for the state); Commonwealth v. Viscosky, 83 Pa. Super. 96, 99-102 (1924) (upholding a defendant's conviction when "the jury were in possession of all the facts" surrounding a codefendant's testimony).

31. Zuern, 101 F. Supp. $2 d$ at 954.

32. Id. at 956 .

33. See supra notes 21-22 and accompanying text. 
and Giglio ${ }^{34}$ failed to disclose a plea agreement with a material witness and fellow inmate, Wayne Lewis. ${ }^{35}$

Although Lewis had been sentenced to prison for a maximum of ten years for violating his probation, he testified for the prosecution without the benefit of a formal agreement. ${ }^{36}$ Lewis testified that "Zuern had expressed animus toward the guards. Thus, his testimony was important in establishing prior calculation and design., ${ }^{37} \mathrm{Al}-$ though both Lewis and the prosecution denied the existence of an agreement, "[w]ithin a matter of days after having testified... the state filed a motion to mitigate Lewis' sentence. Shortly thereafter, the judge who had sentenced Lewis suspended further execution of that sentence." ${ }^{38}$ Thus, Lewis was released from prison and avoided the possibility of a ten-year sentence only days after testifying for the prosecution against Zuern.

"According to Zuern, the temporal proximity between Lewis' testimony and the suspension of his sentence demonstrate[d] that Lewis provided that testimony pursuant to an agreement with the prosecution." ${ }^{39}$ The trial court reasoned that "given Lewis' experience with the criminal justice system, he would have had an expectation that favorable testimony would result in his being rewarded by the prosecution." ${ }^{40}$ Nevertheless, the trial court ultimately concluded, "such an expectation does not establish that such testimony was the product of having been explicitly promised anything." ${ }^{41}$ The defense unsuccessfully argued "that the foregoing reasoning "countenances the formation of agreements between witnesses and the State, based on winks and nods, implicit understandings, soft words of hope imparted from the State to the witness that [are] never set [in] concrete terms." ${ }^{42}$

Fundamentally, the Zuern court held that although Lewis had a rational expectation of leniency, "nothing prevented [Zuern's] counsel from conducting ... a cross-examination of Lewis" and "asking him whether he hoped to get a benefit from testimony favorable to

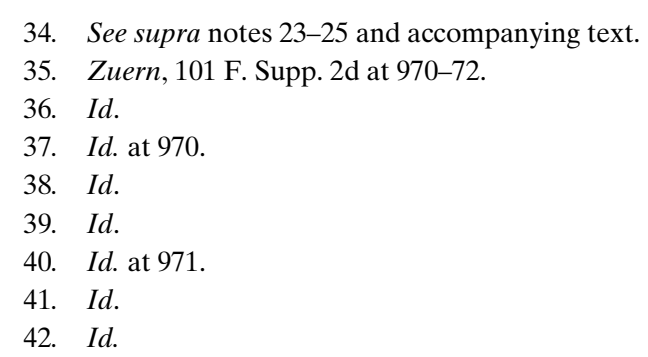


the prosecution." ${ }^{\prime 3}$ Thus, the court concluded that cross-examination was an effective procedural safeguard to secure Zuern's right to a fair trial. $^{44}$

\section{B. An Office Policy of Leniency}

In Darden v. United States, ${ }^{45}$ Charles Darden was convicted of transporting heroin across the United States-Mexican border. ${ }^{46}$ Darden appealed his conviction, arguing that the testimony of a coconspirator, Sadie Mae Roberts, was obtained because the codefendant "could have reasonably believed that she would receive lenient treatment if she testified against appellant." ${ }^{47}$ The defense argued that the United States Attorney's Office had an undisclosed office policy of prosecuting drug traffickers for lesser offenses if they cooperated with the prosecution in convicting a "bigger fish." ${ }^{48}$ Roberts knew she had to implicate Darden to benefit from the policy. ${ }^{49}$ The court readily recognized that "[b]oth Miss Roberts and her attorney were aware

43. Id. at 971 n.21.

44. As Part IV.B demonstrates, however, cross-examination is ineffective as a method of revealing a witness's prejudices to the jury because such witnesses appear cloaked in a veil of absolution and repentance (because they are waiving their rights against self-incrimination) and because the scope of cross-examination is often limited (in that the attorney is unable to fashion precise, nonrepetitive questions beyond "were you promised anything for your testimony?"). See infra notes 151-59 and accompanying text. Interestingly, the prosecution did admit that a basic understanding existed between the prosecution and Lewis. Zuern, 101 F. Supp. 2d at 971. Namely, if Lewis testified for the prosecution, then "if anyone asked, the prosecutor would indicate that he had testified." Id. Presumably, the only person of any consequence at trial who would ask would be a judge. Thus, an agreement did exist to a certain extent, although the consideration Lewis was to receive was ambiguous. One should remember that plea bargains generally are governed by the principles of contract law. E.g., United States v. Allerheiligen, Nos. 99-3144, 99-3154, 2000 U.S. App. LEXIS 18529, at *46 (10th Cir. Aug. 1, 2000). The Restatement (Second) of Contracts states that when interpreting an ambiguous term in a contract, "course of performance is given greater weight than course of dealing or usage of trade." Restatement (SECOND) OF CONTRACTS § 203(b) (1981). Primarily, the American Law Institute thought that course of performance, apart from express unambiguous language, is the most reliable way to ascertain the intentions of two contracting parties. Id. $\S 203$ (b). In this particular case, the course of performance was the state's motion to commute Lewis's sentence. Zuern, 101 F. Supp. $2 \mathrm{~d}$ at 970 . Thus, Zuern, in a commercial setting, certainly could establish the existence of an agreement between the state and Lewis through basic contract principles. However, for some inexplicable reason, the courts seem to hold that the principles of contract law provide more protection to consumers, construction workers, and manufacturers than to criminal defendants.

45. 405 F.2d 1054 (9th Cir. 1969).

46. Id. at 1055 .

47. $I d$.

48. Id.

49. Id. 
of this policy, and the consequent advantage to Miss Roberts to testify that her involvement was limited to her own use of the heroin." ${ }^{50}$ Thus, Roberts's testimony was inherently unreliable because of her "strong motivation to implicate [Darden] and to exonerate" herself. However, the Ninth Circuit upheld the conviction holding that "there was not even a promise or an agreement .... There is only [the codefendant's] reliance on the past policy of the United States Attorney's Office." ${ }^{, 2}$ Therefore, "[t]he fact of a bargain, or of the hope or expectation of leniency affect[ed] only the weight of the testimony, not its admissibility." ${ }^{53}$

In essence, the Darden court held that Darden's right to a fair trial was protected because "[t]he jury decided adversely to appellant under proper instructions." $" 54$

\section{A Prosecutor's Prior Course of Conduct}

In Johnston $v$. Love, ${ }^{55}$ the defendant James Johnston filed a writ of habeas corpus arguing that his multiple murder convictions should be reversed because the prosecution failed to disclose the contents of an agreement between the state and James Griffin, a material and incriminating state witness. ${ }^{56}$ At trial, Griffin testified that he overheard a conversation in which Johnston discussed and planned the criminal acts. $^{57}$ At the time of his testimony, Griffin was incarcerated for burglary and had a charge of conspiracy to commit a triple homicide pending. ${ }^{58}$ On direct and cross-examination at trial, Griffin stated that he did not have any deal with the prosecution. ${ }^{59}$ However, after Johnston's conviction, the Commonwealth dismissed the conspiracy charges pending against Griffin. ${ }^{60}$

\footnotetext{
50. $I d$.

51. See infra note 121 and accompanying text.

52. Darden, 405 F.2d at 1056.

53. Id.

54. Id. However, as Parts III.B and IV.C demonstrate, jury instructions do not effectively reveal and jurors do not fully understand how prejudiced a witness testifying with a rational expectation of leniency is likely to be.

55. No. 94-3727, 1995 U.S. Dist. LEXIS 21426 (E.D. Pa. Oct. 18, 1995).

56. Id. at $* 28-* 29$.

57. $I d$. at $* 27$.

58. Id. at $* 30-* 31$.

59. Id. at $* 27$.

60. Id. at $* 31$.
} 
In a subsequent state court evidentiary hearing, Griffin and his attorney testified that no promises, plea agreements, or understandings were made with the prosecution before or during the trial of Johnston. ${ }^{61}$ However, Griffin's attorney did testify "that he knew, based on his 'experience', that if his client cooperated fully with the Chester County authorities, he would be treated 'fairly' by them when they decided what sentence Mr. Griffin should receive and whether additional criminal charges would be filed." ${ }^{22}$ Moreover, the attorney testified that his "primary motive in agreeing to have $\mathrm{Mr}$. Griffin testify without a plea bargain was to have his client avoid a sentence which included a term of imprisonment." ${ }^{63}$ Although the attorney had extensive experience with the prosecutorial methodology of the county authorities, the district court held that an attorney's rational "expectation of leniency [does] not have to be disclosed to the defense, [even] assuming the Commonwealth [is] aware of it." ${ }^{64}$

The court in Love relied on Alderman v. Zant $t^{65}$ in holding that "a belief by an attorney 'that his client may be in a better position to negotiate a reduced penalty should he testify against a co-defendant is not an agreement within the purview of Giglio." ${ }^{, 66}$ However, the $A l$ derman court had recognized that "[e]ven mere 'advice' by a prosecutor concerning the future prosecution of a key government witness may fall into the category of discoverable evidence since it constitutes an informal understanding which could directly affect the witness's credibility before the jury." ${ }^{, 67}$ Nevertheless, the Love court must have concluded that the difference between "mere advice" and the specific experience of a seasoned attorney, coupled with the past course of conduct of an individual prosecutor, was significant enough to warrant an affirmation of Johnston's conviction.

\section{THE TwIN DANGERS OF THE Formal PlEA BARGAIN}

The traditional plea bargain between a testifying codefendant and a prosecutor has been the subject of considerable academic and

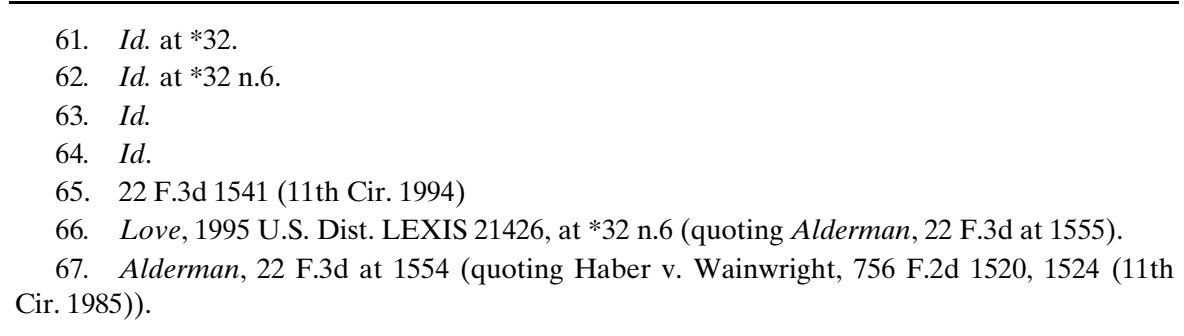


judicial controversy. At the heart of this controversy is a justified fear that the veracity and reliability of incriminating testimony is compromised by a market exchange. ${ }^{68}$ Courts and commentators have recognized that a plea bargain creates two dangers to the integrity of the judicial process and to the administration of justice; leniency creates a motivation to $\operatorname{lie}^{69}$ and encourages codefendants to shift blame. ${ }^{70}$ Writing for the Fifth Circuit Court of Appeals, Judge Eugene Davis articulated the first concern by observing that "[i]t is difficult to imagine a greater motivation to lie than the inducement of a reduced sentence." The Supreme Court recognized this danger of fabrication in Hoffa $v$. United States. ${ }^{72}$ In this Part, I examine recent cases that question the reliability of accomplice testimony resulting from formal plea bargains.

\section{A. The First Danger: Singleton and Motivations to Lie}

A panel of the Tenth Circuit Court of Appeals recently criticized the use of bargained-for testimony in United States $v$. Singleton. In Singleton I, Sonya Singleton appealed her narcotics conviction, arguing that the prosecution obtained crucial testimony by offering leniency to witnesses in violation of the federal antibribery statute codified at 18 U.S.C. $\S 201(\mathrm{c})(2) .^{73}$ The antibribery statute states that "[w]hoever ... directly or indirectly, gives, offers, or promises anything of value to any person, for ... testimony ... shall be fined under this title or imprisoned for not more than two years, or both., ${ }^{, 74}$ Singleton's argument was unique and shocking because it questioned, with a seemingly clear congressional statute that supported her position, the "legality" of the ingrained and institutionalized method of inducing witnesses to testify.

68. See, e.g., United States v. Kimble, 719 F.2d 1253, 1254-57 (5th Cir. 1983) (noting that the witness admitted lying more than thirty separate times when a plea agreement required cooperative testimony in return for a lenient sentence).

69. See infra note 72 and accompanying text.

70. Cf. Williamson v. United States, 512 U.S. 594, 599-600 (1994) (noting that a lenient interpretation of Federal Rule of Evidence 804(b)(3) could encourage declarants to "mix falsehood with truth," see infra notes 91-101 and accompanying text).

71. United States v. Cervantes-Pacheco, 826 F.2d 310, 315 (5th Cir. 1987); accord Singleton I, 144 F.3d 1343, 1350 (10th Cir. 1998) ("[I]t is difficult to imagine anything more valuable than personal physical freedom."), rev'd en banc, 165 F.3d 1297 (10th Cir. 1999).

72. 385 U.S. 293, 311 (1966).

73. Singleton I, 144 F.3d at 1343.

74. 18 U.S.C. $\$ 201(c)(2)-(3)$ (2000). 
The Tenth Circuit panel held that the promises of leniency made by the government in exchange for testimony against Singleton violated the federal antibribery statute. ${ }^{75}$ The Singleton I panel explicitly conceded that its decision "rest[ed] in no way on the Constitution" and was a "creature solely of statute." ${ }^{, 76}$ However, in dicta, the panel repeatedly questioned the ethical propriety of bargained-for testimony by making statements in the following vein: "The promise of intangible benefits imports as great a threat to a witness's truthfulness as a cash payment." 77 The decision created so much controversy and anxiety in prosecutors' offices that the Tenth Circuit vacated the panel ruling on its own motion and ordered a rehearing en banc. ${ }^{78}$

In Singleton II, the full Tenth Circuit overturned the panel's decision and held that the antibribery statute "d[id] not apply to the United States or an Assistant United States Attorney functioning within the official scope of the office." 79 The court reasoned that a prosecutor is a representative of the state in its sovereign capacity, and thus the word "whoever" in 18 U.S.C. § 201(c)(2), which connotes an application to persons and not to entities, did not apply to the government. ${ }^{80}$ Moreover, and more persuasively, the court noted that the plea bargain is "ingrained in our criminal justice system," and therefore it "must [be] presume[d] [that] if Congress had intended that [the antibribery statute] overturn this ingrained aspect of American legal culture, it would have done so in clear, unmistakable, and unarguable language." ${ }^{82}$ Although Singleton II seemingly saved the institution of bargained-for testimony from statutory ruin, neither the case nor the court could quell the academic uproar that Singleton I spawned.

Singleton I embodied a concern shared by academics, defense lawyers, and defendants: that inducing a witness to testify creates a

75. Singleton I, 144 F.3d at 1351.

76. Id. at 1361.

77. Id. at 1350

78. Singleton II, 165 F.3d 1297 (10th Cir. 1999).

79. Id. at 1298 .

80. Id. at 1300. Does this argument mean that corporations, as "entities," cannot be prosecuted under the federal antibribery statute for purchasing favorable testimony? See id. (emphasizing that "whoever" refers to a person, not to an inanimate entity).

81. Id. at 1301 (citing The Whiskey Cases, 99 U.S. 594, 599-600 (1878)).

82. Id. at 1302 . 
danger of fabrication. ${ }^{83}$ Although the Singleton I panel explicitly stated that its decision rested solely on statutory construction, it was clear from the reasoning, tone, and dicta of the decision that the panel believed that the antibribery statute ought to apply to the government. $^{84}$ The panel speculated that $\S 201(\mathrm{c})(2)$ was enacted because bargained-for testimony is "violative of public policy" ises of immunity or leniency premised on cooperation ... may provide a strong inducement to falsify" testimony. ${ }^{86}$ Therefore, the panel interpreted the section broadly as applicable to the government because one "obvious purpose of the blanket prohibition in $\S 201$ [was] to keep testimony free of all influence so that its truthfulness is protected." ${ }^{87}$ Interestingly, the panel never addressed why the antibribery statute had never been applied to the government in the thirty-five years since its enactment. ${ }^{88}$ However, the court in dicta asserted that the application of $\S 201$ (c)(2) to the government was paramount to the justice system:

The judicial process is tainted and justice cheapened when factual testimony is purchased, whether with leniency or money. Because prosecutors bear a weighty responsibility to do justice and observe the law in the course of a prosecution, it is particularly appropriate to apply the strictures of $\S 201$ (c)(2) to their activities. ${ }^{89}$

Even assuming that Singleton I was decided wrongly, the decision is relevant because it typifies judicial skepticism toward the veracity of bargained-for testimony. The Supreme Court and almost every federal circuit court of appeals has questioned the sincerity and accuracy of incriminating accomplice testimony given pursuant to a coop-

83. See, e.g., James P. Dowden, United States v. Singleton: A Warning Shot Heard Round the Circuits?, 40 B.C. L. REV. 897, 933 (1999) (arguing that in an accomplice plea agreement "a defendant is potentially exposed to false testimony that is cloaked with the power and majesty of the U.S. government leading many jurors to presumptively believe its validity"); Timothy Hollis, An Offer You Can't Refuse? United States v. Singleton and the Effects of Witness/Prosecutorial Agreements, 9 B.U. PUB. INT. L.J. 433, 434 (2000) (asserting that "prosecutorial deals" in exchange for testimony "create an incentive for informants to lie").

84. Singleton I, 144 F.3d 1343, 1346-48 (10th Cir. 1998).

85. Id. at 1347.

86. Id. at 1350 (quoting United States v. Meinster, 619 F.2d 1041, 1045 (4th Cir. 1980)).

87. Id.

88. The court did address three other cases in which a criminal defendant had appealed a conviction and argued that crucial testimony was admitted in violation of $\S 201(\mathrm{c})(2)$, finding each case unpersuasive. See id. at 1356-58.

89. Id. at 1347. 
eration agreement. ${ }^{90}$ However, courts have relied on full disclosure and the adversary system to justify, uphold, and preserve the institution of witness inducements.

\section{B. The Second Danger: Williamson and the Tendency to Shift Blame}

"Accomplice plea agreements tend to produce unreliable testimony because they create an incentive for the accomplice to shift blame to the defendant or other co-conspirators." "91 Accomplices' motivations to shift blame have been analyzed exhaustively by courts and academics under the hearsay exception for statements against penal interests codified in Federal Rule of Evidence 804(b)(3). This exception allows the prosecutor to admit into evidence a statement against the penal interests of the declarant at trial when the declarant is unavailable, the declarant had an understanding that the statement was against his or her penal interests, and a reasonable person would not have made the statement unless he or she believed it to be true. ${ }^{92}$ What is interesting about Rule 804(b)(3) is that courts often admit a declarant's statement inculpating a codefendant uttered by the declarant as part of a self-inculpatory narrative. The jurisprudence applying Rule 804(b)(3) in this fashion sheds substantial light on the motivation of a declarant-defendant to shift blame and make statements tending to subject another codefendant to criminal liability.

90. The Supreme Court dealt with the issue of accomplice plea bargains and the veracity of that testimony in two landmark cases. See Giglio v. United States, 405 U.S. 150, 154-55 (1972) (holding that the prosecutor's failure to disclose a promise of leniency in exchange for a coconspirator's testimony constituted a violation of due process that required a new trial); Hoffa v. United States, 385 U.S. 293, 311 (1966) (holding that the testimony of a paid informer is constitutionally permissible, even though the informer "may have had motives to lie," due to crossexamination and trial by jury). Likewise, some federal circuit courts have encountered the problem directly. See, e.g., United States v. Cervantes-Pacheco, 826 F.2d 310, 315 (5th Cir. 1987) (holding that testimony in exchange for monetary compensation is no different than testimony in exchange for a reduced sentence and will be admitted); United States v. Meinster, 619 F.2d 1041, 1045 (4th Cir. 1980) (finding no motive for falsification where the witness was not promised anything in exchange for his testimony).

91. Yvette A. Beeman, Accomplice Testimony Under Contingent Plea Agreements, 72 CORNELl L. REV. 800, 802 (1987); see also Kyles v. Whitley, 514 U.S. 419, 461 (1995) (Scalia, J., dissenting) (" $\mathrm{I}] \mathrm{t}$ is not unusual for a guilty person who knows that he is suspected of a crime to try to shift blame to someone else ...."); Whelchel v. Washington, 232 F.3d 1197, 1208 (9th Cir. 2000) (asserting that one possible reason for a witness to testify falsely is "to shift blame when plea bargaining for a lighter sentence").

92. 4 David W. Louisell \& Christopher B. Mueller, Federal Evidence $§ 489$, at 1128-31 (1980). 
The federal rules of evidence maintain that hearsay-out-ofcourt statements offered for the truth of the matter asserted ${ }^{93}$-is inadmissible unless an exception applies. ${ }^{94}$ This rule reflects the Advisory Committee's concern that the trustworthiness and reliability of hearsay is suspect because the statements are not given under oath and the testimony is not subject to a vigorous cross-examination to reveal defects in the declarant's perception, memory, or articulation. ${ }^{95}$ Moreover, when hearsay statements are admitted, the factfinder is deprived of the opportunity to closely observe and scrutinize the demeanor of the declarant on the witness stand. ${ }^{96}$ Thus, hearsay statements are generally inadmissible because the reliability and trustworthiness of the testimony cannot be effectively guaranteed by the adversary system.

However, the Federal Rules of Evidence have carved out myriad exceptions to the general prohibition. ${ }^{97}$ Primarily, these exceptions are based on situations in which the probative value and necessity of admitting the hearsay statement is substantial and the circumstances under which the statement was uttered indicate "indicia of reliability sufficient to overcome the dangers typically posed by hearsay." ${ }^{\circ 8}$ One of these exceptions recognizes that when an individual makes a statement against proprietary or penal interests-"I just robbed the bank" - that statement is extremely probative and sufficiently reliable because a reasonable person would not subject himself to criminal liability unless he believed the truth of the matter asserted. ${ }^{99}$

When drafting this exception in 1969, the Advisory Committee recognized that statements against an individual's penal interest possess indicia of reliability. ${ }^{100}$ However, the Committee noted that such

93. FED. R. EVID. 801.

94. Id. 802 .

95. 5 John Henry Wigmore, EVidence in Trials at COMMON LAW $\S 1362$, at 3 (James H. Chadbourn ed., rev. ed. 1974).

96. See, e.g., Henry S. Sahm, Demeanor Evidence: Elusive and Intangible Imponderables, 47 A.B.A. J. 580, 580-81 (1961) (quoting numerous authorities discussing the importance of demeanor evidence).

97. FED R. EVID. 803-807.

98. Emily F. Duck, The Williamson Standard for the Exception to the Rule Against Hearsay for Statements Against Penal Interest, 85 J. CRIM. L. \& CRIMINOLOGY 1084, 1085 (1995).

99. FED. R. EvID. 804(b)(3).

100. See Preliminary Draft of the Proposed Rules of Evidence for the United States District Courts and Magistrates, 46 F.R.D. 161, 385 (1969) ("The circumstantial guaranty of reliability for declarations against interest is the assumption that persons do not make statements which are damaging to themselves unless satisfied for good reason that they are true."). 
statements should be admissible only against the declarant, and that statements inculpating a codefendant should be inadmissible. ${ }^{101}$ Primarily, the Committee reasoned that "statements of codefendants have traditionally been regarded with suspicion because of the readily supposed advantages of implicating another."102 Therefore, the Committee explicitly limited the hearsay exception: "This example does not include a statement or confession offered against the accused in a criminal case, made by a codefendant or other person implicating both himself and the accused." ${ }^{, 103}$ Nevertheless, when the Supreme Court issued the final draft of this hearsay exception, it omitted the Advisory Committee's limitation on the admission of statements inculpating codefendants. ${ }^{104}$

Traditionally, the case law interpreting Rule 804(b)(3) determined the reliability and admissibility of a statement inculpating a codefendant by analyzing whether the incriminating statements were uttered as part of a larger self-inculpatory narrative. ${ }^{105}$ For example, in United States v. Lieberman, ${ }^{106}$ the Second Circuit Court of Appeals held that statements of a co-conspirator were admissible against a codefendant, even if the statements were more damaging to the codefendant than the declarant, if the statements were "part and parcel" of a self-inculpatory narration. ${ }^{107}$ However, since the enactment of Rule 804(b)(3), the federal appeals courts have varied their approaches to and interpretation of this exception. Therefore, the Supreme Court granted certiorari in Williamson v. United States ${ }^{108}$ to "clarify the scope of the hearsay exception for statements against penal interest." 109

\footnotetext{
101. Id. at 386 .

102. Id.

103. Id. at 378.

104. FED. R. EVID. 804(b)(3).

105. See, e.g., United States v. Coachman, 727 F.2d 1293, 1297 (D.C. Cir. 1984) (holding that a third party's self-inculpatory statements were against his penal interests and admissible because his "version did not attempt to trivialize his own involvement in the nefarious scheme by shifting responsibility to his cohorts; rather, it frankly disclosed the extent of his own participation without any effort to demonstrate that others were really the ones to blame").

106. 637 F.2d 95 (2d Cir. 1980).

107. Id. at 103 (holding that a declarant's admission was admissible as a statement against penal interests against a codefendant when the codefendant told him not to open the storeroom door for anyone when they were engaged in marijuana trafficking because it demonstrated the declarant's knowledge and was therefore inculpating against both the declarant and the codefendant).

108. 512 U.S. 594 (1994).

109. Id. at 596 .
} 
In Williamson, the defendant appealed his narcotics conviction to the United States Supreme Court, arguing that the trial court erred when it admitted an incriminating confession made by an accomplice under Rule 804(b)(3). ${ }^{110}$ The police in Williamson stopped the declarant, Reginald Harris, for weaving on the highway. ${ }^{111}$ Harris consented to a search of his vehicle, and the police discovered nineteen kilograms of cocaine in the trunk. ${ }^{112}$ After fabricating a story, Harris made a confession to Agent Walton of the Drug Enforcement Agency in which he admitted transporting the cocaine for Williamson. ${ }^{113}$ Additionally, in the course of his confession, Harris noted that Williamson was traveling in a car in front of Harris, and that Williamson had turned around after the police stopped Harris and could see that the truck was being searched. ${ }^{114}$ At trial, Harris refused to testify against Williamson even though the state offered him use immunity and the court held him in contempt for his refusal. ${ }^{115}$ On a motion by the prosecution, the district court ruled that Agent Walton could relate the confession of Harris, including the statements that inculpated Williamson, to the jury under Rule 804(b)(3). ${ }^{116}$

Writing for the Court, Justice Sandra Day O'Connor held that "the most faithful reading of Rule 804(b)(3) is that it does not allow admission of non-self-inculpatory statements, even if they are made within a broader narrative that is generally self-inculpatory." ${ }^{117}$ Justice O'Connor wrote that Rule 804(b)(3) was founded on the principle "that reasonable people, even reasonable people who are not especially honest, tend not to make self-inculpatory statements unless they believe them to be true." 118 However, Justice O'Connor noted that "[t]he fact that a person is making a broadly self-inculpatory confession does not make more credible the confession's non-selfinculpatory parts," because one of the most effective methods of deceiving is to mix truth with falsehood. ${ }^{119}$ This deception is particularly persuasive when the truth is self-inculpatory because the declarant is

\footnotetext{
110. Id. at 598.

111. Id. at 596 .

112. Id.

113. Id. at 597.

114. Id.

115. Id.

116. Id. at 597-98.

117. Id. at $600-01$.

118. Id. at 599.

119. Id.
} 
cloaked in a veil of absolution and repentance. ${ }^{120}$ Moreover, Justice O'Connor reiterated a judicial principle that directly contradicts the idea that incriminating statements by a codefendant should be given substantial weight: "The arrest statements of a codefendant have traditionally been viewed with special suspicion. Due to his strong motivation to implicate the defendant and to exonerate himself, a codefendant's statements about what the defendant said or did are less credible than ordinary hearsay evidence." ${ }^{\prime 121}$

Like prosecutors' use of Rule 804(b)(3) before Williamson, prosecutors' use of accomplice plea agreements poses a difficulty for the factfinder. Because the testifying accomplice has pleaded guilty and openly admits his role in the criminal activity, his falsehoods and blame-shifting might appear more persuasive to a jury; they are mixed with the truth and self-inculpatory statements. However, many courts consider the risk of prejudice and perjury to be counterbalanced by full disclosure, confrontation, and the ability of a properly instructed jury to reasonably judge the credibility and weight of each piece of evidence and testimony.

\section{The Procedural SAFEguards Protecting the ACCuSED}

The Supreme Court has recognized that the Federal Rules of Evidence have a "liberal thrust" favoring the admission of relevant evidence. ${ }^{122}$ Although the Federal Rules provide that relevant evidence may be inadmissible if the likely prejudice of the evidence substantially outweighs its probative value, there are troublesome situations where evidence is both highly probative and prejudicial. For instance, the testimony of an accomplice against a codefendant, obtained by the prosecution in exchange for leniency or immunity, is illustrative of a situation in which evidence is highly probative and prejudicial. In these situations, the courts must balance the probative value of eyewitness, insider testimony against the twin dangers of accomplice testimony. However, when the scales of prejudice and pro-

120. See id. at 599-600 (noting that truth is particularly persuasive when it has a "selfinculpatory nature").

121. Id. at 601 (quoting Lee v. Illinois, 476 U.S. 530, 541 (1986)).

122. Daubert v. Merrell Dow Pharms., Inc., 509 U.S. 579, 588 (1993); Beech Aircraft Corp. v. Rainey, 488 U.S. 153, 169 (1988). The Federal Rules of Evidence require a trial court to admit relevant evidence-evidence having any tendency to make a fact of consequence more or less probable-unless the prejudicial effect of that evidence substantially outweighs the evidence's probative value. FED. R. EVID. 401-403. 
bativity are equally substantial, the "liberal thrust" of the evidence rules direct the courts to admit the testimony. ${ }^{123}$

The Federal Rules of Evidence and the judiciary rely on other procedural safeguards to expose the infirmities of such evidence to the jury and to protect the accused. For example, in Hoffa v. United States, ${ }^{124}$ the United States Supreme Court addressed the issue of whether bargained-for testimony creates a motivation to lie that jeopardizes the constitutional rights of the accused under the Due Process Clause of the Fifth Amendment. ${ }^{125}$ The Court considered whether this relevant and highly probative testimony was so prejudicial that the adversary system was a constitutionally ineffective method of protecting the rights of the accused. The Court explicitly recognized the danger of fabrication, but the Court reasoned that this danger did not mandate constitutional inadmissibility because the accused is protected by "[t]he established [procedural] safeguards of the Anglo-American legal system." 126 These established safeguards include the right of the accused to confront and cross-examine witnesses, the role of the judge in properly instructing the jury on the law, and the duty of the jury to follow the spirit and letter of these instructions. ${ }^{127}$

\section{A. Confrontation, Cross-Examination, and Discovery}

The right to cross-examine witnesses is the fundamental procedural safeguard protecting the accused from the twin dangers of bargained-for accomplice testimony. The Sixth Amendment guarantees the accused the right to confront adverse witnesses. ${ }^{128}$ The Supreme Court and academics have recognized that "cross-examination is the core component" of the Confrontation Clause ${ }^{129}$ because "it is the

\footnotetext{
123. FED. R. EVID. 403.

124. 385 U.S. 293 (1966).

125. Id. at $310-11$.

126. Id. at 311.

127. Id.

128. Pointer v. Texas, 380 U.S. 400, 404-05 (1965) (holding that the right of crossexamination is part of an accused's right to confront adverse witnesses); see also Davis v. Alaska, 415 U.S. 308, 315 (1974) ("Confrontation means more than being allowed to confront the witness physically. 'Our cases construing the [Confrontation] clause hold that a primary interest secured by it is the right of cross-examination.'”) (quoting Douglas v. Alabama, 380 U.S. 415, 418 (1965)).

129. E.g., Frank T. Read, The New Confrontation-Hearsay Dilemma, 45 S. CAL. L. REv. 1, 49 (1972) ("[C]ross-examination is the core component to be preserved-because it is essential to our adversary system ....").
} 
very heart of an adversary theory of litigation." ${ }^{, 130}$ Cross-examination tests the reliability of evidence and preserves the "fundamental principle of our adversary system [that] maintains that a factfinder should ... not rely on the words of a witness" until the opponent has had the opportunity for cross-examination. ${ }^{131}$

The Fifth Amendment's Due Process Clause requires the government "to disclose to the defense and to the trial jury the existence of plea bargaining negotiations with a key witness." 132 The disclosure of a formal plea agreement enables the defense to cross-examine the witness about his motivations for testifying, any tangible benefits he will gain from incriminating the defendant, and the possibility that the declarant is merely shifting blame. The failure of the government to disclose a plea agreement is a violation of the defendant's due process rights and grounds for reversal. ${ }^{133}$ In Napue v. Illinois, the Supreme Court held that the "jury's estimate of the truthfulness and reliability of a given witness may well be determinative of guilt or innocence, and it is upon such subtle factors as the possible interest of the witness in testifying falsely that a defendant's life or liberty may depend." ${ }^{134}$ Therefore, evidence of a testifying codefendant's plea agreement with the government tends to impeach the codefendant's credibility and exculpate the accused, and, in accord with Brady $v$. Maryland, ${ }^{135}$ the "suppression by the prosecution of [such] evidence ... violates due process."

Thus, the courts and many academics agree that the accused is protected from the twin dangers of accomplice testimony because the

130. Model Code OF EvID. 221 (1942); cf. Davis, 415 U.S. at 315 ("Confrontation means more than being allowed to confront the witness physically.").

131. Randolph N. Jonakait, Restoring the Confrontation Clause to the Sixth Amendment, 35 UCLA L. REV. 557, 586 (1988) (describing the "clear" role of confrontation in the adversary system).

132. United States v. Fontenot, 483 F.2d 315, 325 (5th Cir. 1973) (holding that a failure to disclose such information "deprives a defendant of Fifth Amendment due process of law"); see also Giglio v. United States, 405 U.S. 150, 155 (1972) (same).

133. See Giglio, 405 U.S. at $154-55$ (stating that when a witness's reliability may be determinative of guilt or innocence, nondisclosure of evidence affecting the witness's credibility falls within the general rule that suppression of material evidence justifies a new trial); see also Napue v. Illinois, 360 U.S. 264, 272 (1959) (holding that a failure by the government to correct knowingly false testimony about the existence of a plea agreement violated the Fifth Amendment rights of the accused).

134. Napue, 360 U.S. at 269.

135. 373 U.S. 83 (1963).

136. Id. at 87 . 
defense is armed with the right of cross-examination and the details of the accomplice's plea agreement.

\section{B. Jury Instructions}

The Federal Rules of Criminal Procedure provide that "any party may file written requests that the court instruct the jury on the law." ${ }^{137}$ Jury instructions are intended "to focus [the jury's] attention on the essential issues in the case and inform [the jury] of the permissible ways in which these issues may be resolved." 138 Jury instructions also function to inform the jury about issues of credibility, motivation, and interest. Thus, when the government calls an accomplice to testify, the trial judge may give the jury an instruction in the following vein:

[A]ccomplice testimony is of such nature that it must be scrutinized with great care and viewed with particular caution when you decide how much of that testimony to believe.

You should ask yourselves whether these so-called accomplices would benefit more by lying, or by telling the truth. Was their testimony made up in any way because they believed or hoped that they would somehow receive favorable treatment by testifying falsely? Or did they believe that their interests would be best served by testifying truthfully? If you believe that the witness was motivated by hopes of personal gain, was the motivation one which would cause him to lie, or was it one which would cause him to tell the truth? Did this motivation color his testimony?

In sum, you should look at all of the evidence in deciding what credence and what weight, if any, you will want to give to the accomplice witnesses. ${ }^{139}$

137. FED. R. CRIM. P. 30.

138. United States v. Ribaste, 905 F.2d 1140, 1143 (8th Cir. 1990); see also United States v. Lewis, 53 F.3d 29, 34 (4th Cir. 1995) ("The purpose of jury instructions is to instruct the jury clearly regarding the law to be applied in the case."); United States v. Assi, 748 F.2d 62, 65 (2d Cir. 1984) ("The purpose of jury instructions is to inform the jury clearly and succinctly of the role it is to play and the decisions it must make.").

139. 1 LEONARD B. SAND ET AL., MOdERn FEDERAL JURy InSTRUCTIONS $\mathbb{~ I l ~ 7 . 0 1 , ~ a t ~ 7 - 1 7 ~}$ to 7-18 (1992) ("Instruction 7-5: Accomplices Called by the Government"); see also COMM. ON Model Criminal Jury Instructions Within the Ninth Circuit, Manual of Model CRIMINAL JURY INSTRUCTIONS 4.11 (2000) [hereinafter NINTH CIRCUIT JURY INSTRUCTIONS] 
In all the federal circuits, district courts use specific pattern jury instructions that address the credibility of bargained-for testimony obtained from either an accomplice or a paid informant. ${ }^{140}$ Many appeals courts have held that the trial court's failure to give an "admonitory instruction to scrutinize an accomplice's testimony" can be reversible error because such an instruction is an essential procedural method to secure a fair trial for the accused. ${ }^{141}$ Jury instructions questioning the credibility of accomplice testimony serve two essential procedural functions. First, the instruction reinforces the defense's cross-examination by attacking the generalized trustworthiness of accomplice testimony. Second, the instruction protects the accused from ineffective, or limited, cross-examination that fails to apprise the jury of the devious motivations inherent in codefendant testimony. Thus, jury instructions on witness credibility serve as a second procedural safeguard protecting the accused from the twin dangers of accomplice testimony.

("You should consider such testimony with greater caution than that of an ordinary witness."); Judicial Council of the Eleventh CiRCuit, Eleventh Circuit Pattern Jury InSTRUCtions (CRIMINAL CASES) 1.1 (1997) [hereinafter ElEVEnTH CirCuit JuRy INSTRUCTIONS]:

The testimony of some witnesses must be considered with more caution than the testimony of other witnesses. For example, a paid informer, or a witness who has been promised that he or she will not be charged or prosecuted, or a witness who hopes to gain more favorable treatment in his or her own case, may have a reason to make a false statement because the witness wants to strike a good bargain with the Government.

140. See, e.g., Comm. On PAttern Jury Instructions, Dist. Judges Ass'N, Fifth Circuit, PATTERn Jury Instructions (CRIMINAl CASES) 1.15 (1997) [hereinafter FifTH CIRCUIT JURY INSTRUCTIONS] (“Accomplice-Informer-Immunity” instruction); COMM. ON FED. CRIMINAL JURy INSTRUCTIONS FOR THE SEVENTH CiRCUIT, PATTERn CRIMINAL JURY INSTRUCTIONS FOR THE SEVENTH CIRCUIT 3.13 (1998) [hereinafter SEVENTH CIRCUIT JURY INSTRUCTIONS] ("Witnesses Requiring Special Caution" instruction); JUdiCIAL COMM. ON MODEl JURY INSTRUCTIONS FOR THE EIGHTH CIRCUIT, MANUAL OF MODEL CRIMINAL JURY INSTRUCTIONS 4.05 (2000) [hereinafter EIGHTH CIRCUIT JURY INSTRUCTIONS] ("Testimony of Accomplice" instruction); $i d$. at 4.06 ("Testimony of Informer" instruction); NINTH CIRCUIT JURY INSTRUCTIONS, supra note 139, at 4.10 ("Testimony of Informer" instruction); id. at 4.11 ("Testimony of Accomplice" instruction); ELEVENTH CIRCUIT JURY INSTRUCTIONS, supra note 139 , at 1.1 ("Accomplice-Informer-Immunity" test).

141. E.g., United States v. Bernard, 625 F.2d 854, 857 (9th Cir. 1980); United States v. Leonard, 494 F.2d 955, 959-62 (D.C. Cir. 1974); United States v. Gonzalez, 491 F.2d 1202, 1207 (5th Cir. 1974); United States v. Wasko, 473 F.2d 1282, 1284 (7th Cir. 1973); United States v. Davis, 439 F.2d 1105, 1107 (9th Cir. 1971). But see United States v. Shriver, 838 F.2d 980, 983 (8th Cir. 1988) (holding that although giving cautionary instructions is "the better practice," such instruction is not required). 


\section{RATIONAL EXPECTATIONS OF LENIENCY AND THE INEFFECTIVENESS OF ESTABLISHED PROCEDURAL SAFEGUARDS TO PROTECT THE ACCUSED FROM THE TWIN DANGERS}

Courts, academics, and legislatures have recognized the danger of unfair prejudice that accomplice plea bargains create for the accused. ${ }^{142}$ Many of them also have recognized, however, that procedural rules-particularly rules providing for disclosure, rigorous cross-examination, and the proper instruction of a jury-may help lessen the danger. ${ }^{143}$ Conspicuously absent from this debate is an equally pervasive threat: the implicit plea bargain. In the case of implicit plea bargains, the procedural safeguards touted in Hoffa are ineffective. This Part shows that the twin dangers of a formalized plea bargain-motivations to lie and to make self-exculpatory statements-exist regardless of whether an accomplice testifies pursuant to a formal plea bargain. Moreover, this Part describes psychological research demonstrating what circumstances encourage false confessions and the effect of such confessions on the ability of the jury to properly deliberate and weigh the truthfulness of evidence.

\section{A. The Twin Dangers and Incriminating Testimony Absent a Formal Agreement}

Courts recognize that accomplice testimony poses the same danger whether the accomplice is motivated by a formal plea bargain or by the mere expectation of leniency. ${ }^{144}$ Social science research confirms this hypothesis. ${ }^{145}$ For example, a recent study by Professor Saul M. Kassin analyzes whether police are better able to obtain a confession from a criminal defendant by using explicit rather than implicit promises of leniency. ${ }^{146}$

142. See supra Part II.

143. See supra Part III.

144. See, e.g., People v. Wallin, 197 P.2d 734, 737 (Ca. 1948) ("[E]xperience has shown that the evidence of an accomplice should be viewed with care, caution and suspicion because it comes from a tainted source and is often given in the hope or expectation of leniency or immunity.").

145. See, e.g., Saul M. Kassin \& Karlyn McNall, Police Interrogations and Confessions: Communicating Promises and Threats by Pragmatic Implication, 15 LAW \& HUM. BEHAV. 233, 247-48 (1991) (presenting research that suggests that interrogation "minimization" techniques, while seemingly noncoercive, actually may communicate an implicit offer of leniency to the suspect and communicate an assumption to the jury that the interrogator must have had an evidentiary basis for presuming the defendant's guilt).

146. Id. at 234-37. 
Professor Kassin's data indicates that explicit and implicit promises "are functionally equivalent in their impact" on an individual's decision to confess. ${ }^{147}$ Kassin reasons that this result occurs because, as Professors Richard J. Harris and Gregory E. Monaco note in a 1978 study, "people often process information 'between the lines." 148 Therefore, whether a promise of leniency is explicit or implied, the probability of the subject taking action in reliance on those promises is related more to the degree that the subject relies on and trusts the source of the information than to the differentiation the brain makes between the explicit and the implied. ${ }^{149}$ Kassin speculates that both explicit and implicit promises, like threats, "have the potential to coax innocent people into confessing to crimes they did not commit."150

Thus, accomplices place similar reliance on explicit and implicit promises of leniency. Courts "explicitly" have recognized this hypothesis, and social science "implicitly" has confirmed it with an analysis of varying promises in the context of confessions. Nevertheless, the procedural safeguards promulgated by the Court and recognized in Hoffa for safeguarding the justice system from inaccuracy are ineffective to protect the accused from the dangers of unfair prejudice posed by implicit agreements or promises between the government and a testifying witness.

\section{B. Confrontation, Cross-Examination, and Discovery}

Cross-examination of a witness's expectations of leniency is an ineffective method of safeguarding the accused from unfair prejudice for three reasons. First, a plea agreement between the government and any key witness must be disclosed to the defense ${ }^{151}$ however, a witness's rational "expectation of leniency [does] not have to be disclosed to the defense, [even if] the Commonwealth [is] aware of it." ${ }^{152}$

147. Id. at 248 .

148. Id. (citing Richard J. Harris \& Gregory E. Monaco, Psychology of Pragmatic Implication: Information Processing Between the Lines, 107 J. EXPERIMENTAL PSYCHOL. 1, 1-22 (1978)).

149. See id. at 249 (noting that more research is needed to evaluate the effects of tactics designed to establish the interrogator as the subject's ally).

150. Id. at 248.

151. See supra note 132 and accompanying text.

152. Johnston v. Love, No. 94-3727, 1995 U.S. Dist. LEXIS 21426, at *33 (E.D. Pa. Oct. 18, 1995); see also Alderman v. Zant, 22 F.3d 1541, 1555 (11th Cir. 1994) (holding that an attorney's belief "that his client may be in a better position to negotiate a reduced penalty should he testify against a co-defendant is not an agreement within the purview of Giglio"). 
This legal maxim is true even if the expectation of leniency is reasonable and rationally based on past experience or an informal office policy. For instance, in Johnston v. Love, Griffin testified against Love in a murder case. ${ }^{153}$ Griffin was advised by his attorney that "based on [the attorney's] 'experience', that if [Griffin] . . . cooperated fully with the ... authorities, he would be treated 'fairly' by them when they decided what sentence [he] should receive." ${ }^{, 154}$ After the trial, the attorney admitted that his "primary motive in agreeing to have Mr. Griffin testify without a plea bargain was to have his client avoid a sentence which included a term of imprisonment." ${ }^{155}$ However, the attorney's experience, the Commonwealth's previous practice with this particular attorney, and the informal policy of giving witnesses reduced sentences for testifying was neither disclosed nor discoverable by the defense. ${ }^{156}$ Therefore, unlike a formal plea bargain, cross-examination of a witness's rational expectation of leniency is hampered because the expectation is not subject to the procedural safeguards of mandatory disclosure or discovery.

Second, although the defense still has the right to cross-examine the witness about any hopes or expectations he might have, the trial court often forbids the defense from aggressively pursuing the matter. For instance, in United States v. Page, ${ }^{157}$ after the United States Attorney impeached his own witness on direct examination, the defense attempted to elicit testimony about the witness's pending charges to expose her expectations of leniency. ${ }^{158}$ The trial court curtailed the cross-examination because the government already had impeached her credibility on the same point. ${ }^{159}$ The Sixth Circuit held that the trial court properly limited the cross-examination because "[t]he confrontation clause is not violated when a district court . . . reasonably limit[s] cross-examination." 160 Thus, the right of cross-examination is more easily curtailed when the declarant's rational expectation of leniency is not concrete or formalized because the defense is unable to

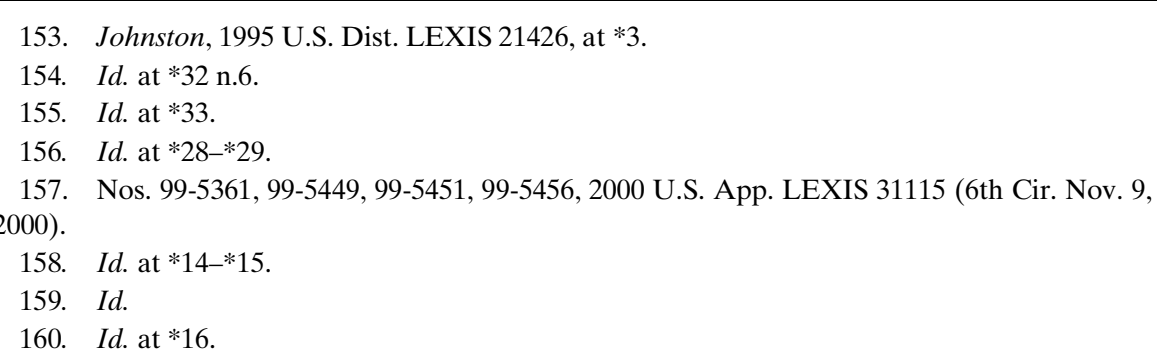


ask precise, nonrepetitive questions to elicit testimony about the witness's reasonable hopes.

Third, an accomplice who testifies without an agreement is cloaked in a practically impenetrable veil of absolution and repentance. The accomplice has waived any Fifth Amendment rights against self-incrimination and has been exposed to conviction. As Justice O'Connor recognized in Williamson, the credibility and weight of the testimony is substantially bolstered because the jury is more likely to believe a defendant whose testimony is self-inculpatory and who "officially" has nothing to gain and everything to lose from testifying under oath. ${ }^{161}$ Moreover, the defense's power to pierce the declarant's veil of credibility is inhibited because the implicit agreement is not discoverable $\mathrm{e}^{162}$ and because the trial court in its discretion can limit cross-examination. ${ }^{163}$

\section{Jury Instructions}

As they are used in American courtrooms, jury instructions are an ineffective method of safeguarding the accused from unfair prejudice caused by an accomplice who testifies without a formal agreement. Although courts have recognized that the dangers of accomplice testimony exist whether or not a formal agreement has been reached, ${ }^{164}$ many courts will not give a cautionary instruction unless the accomplice has a formal plea bargain. For instance, district courts in the Fifth and Eleventh Circuits instruct the jury to be particularly skeptical of a witness's credibility if the witness is a paid informer or a codefendant with a grant of immunity or leniency. ${ }^{165}$ In United States v. Tanios, ${ }^{166}$ "[t] $]$ he defense requested an instruction cautioning the jury on its assessment of the testimony of an accomplice . . . In declining the request, the trial judge stated that there was no evidence of any offer of immunity or leniency and that the traditional instructions on witness credibility were adequate to cover the situation."167

\footnotetext{
161. Williamson v. United States, 512 U.S. 594, 599-600 (1994).

162. See supra note 152 and accompanying text.

163. See supra notes $157-60$ and accompanying text.

164. See supra note 144 and accompanying text.

165. FifTH CIRCUIT JURY INSTRUCTIONS, supra note 140, at 1.14-1.15; ELEVENTH CIRCUIT

JURY INSTRUCTIONS, supra note 139, at 1.1-1.2.

166. 82 F.3d 98 (5th Cir. 1996).

167. Id. at 100.
} 
District courts in the Sixth, Eighth, and Ninth Circuits use different cautionary instructions for an accomplice who testifies with a formal agreement and an accomplice who testifies without a formal agreement. ${ }^{168}$ For instance, when an accomplice testifies under an agreement, courts in the Sixth Circuit instruct the jury to consider the "testimony with more caution than the testimony of other witnesses [and to] [c]onsider whether his testimony may have been influenced by the government's promise." ${ }^{169}$ Moreover, the instruction states that the accomplice would have been prosecuted had he not cooperated, and it describes any other benefits the accomplice received. ${ }^{170}$ However, when an accomplice testifies without an agreement, courts in the Sixth Circuit merely instruct the jury that the testimony should be considered with caution; it fails to instruct the jury that the testimony might be motivated by a promise or an expectation of gain. ${ }^{171}$

Even assuming that cross-examination and jury instructions were sufficient to protect the accused, social science research suggests that-even with these "effective" procedural safeguards-jurors are incapable of rationally weighing the credibility of an accomplice who testifies without a formal plea agreement. ${ }^{172}$

Although research indicates that jurors will concede that a confession obtained through implicit promises is "involuntary' by law," generally "jurors react with ambivalence to confessions elicited by positive forms of inducement." ${ }^{, 173}$ In Kassin's study, mock jurors were presented with transcripts of trials where a confession was obtained either by threats, explicit promises, or a process called minimization, in which implicit promises of leniency are used. ${ }^{174}$ Jurors "fully discounted confessions brought on by threats." ${ }^{, 175}$ Jurors "partially discounted confessions that were prompted by an explicit promise." However, jurors gave substantial credence and weight to confessions

168. COMm. On PATtern Criminal Jury Instructions, Dist. Judges Ass'N, SiXth Circuit, PATtern CRIMINAL JURy InSTRUCtions 7.07-7.08 (1991) [hereinafter SiXTH CiRCUIT JURY INSTRUCTIONS]; EIGHTH CIRCUIT JURY INSTRUCTIONS, supra note 140, at 4.044.05; NINTH CIRCUIT JURY INSTRUCTIONS, supra note 140, at 4.9-4.11.

169. SiXTH CIRCUIT JURY INSTRUCTIONS, supra note 168, at 7.07 .

170. Id.

171. Id. at 7.08 .

172. See Kassin \& McNall, supra note 145, at 248-49 (calling for further research to determine the effects of different interrogation styles upon juror valuations of confessions).

173. Id.

174. Id. at 239-50.

175. Id. at 247.

176. Id. at 247-48. 
obtained by implicit promises of leniency, and although forty-seven percent judged the confession involuntary, these same jurors "proceeded to vote guilty."

Therefore, even if a trial court gives a jury instruction like that given in the Sixth Circuit when an accomplice testifies without a plea bargain, Kassin's data indicate that the jury likely will concede that the accomplice has a motivation to lie. Nevertheless, the jury will give substantially more weight to the testimony of an accomplice without a formal agreement than one who has a formal agreement. This extra weight and credibility is not deserved. As noted before, academics, courts, and social science research all indicate that an accomplice has an equal motivation to lie regardless of whether he testifies with a formal plea agreement or a rational expectation of leniency. ${ }^{178}$

\section{PROpOSED SOLUTIONS}

\section{A. Creating a Discoverable Non-Binding Agreement Between Prosecutors and Codefendants}

"A prosecutor has the responsibility of a minister of justice and not simply that of an advocate. This responsibility carries with it specific obligations to see that the defendant is accorded procedural justice . . . ."179 "[T]he Supreme Court has 'long emphasized' that a prosecutor is held to 'a higher standard of behavior' than defense counsel." ${ }^{180}$ Unlike defense counsel, the prosecutor has an ethical and legal duty to protect the procedural rights of the opposing party. ${ }^{181}$ One such legal duty prevents the prosecution from presenting false evidence and mandates the reversal of any conviction where the prosecutor knew, or reasonably should have known, that false evi-

\footnotetext{
177. Id. at 248.

178. See supra notes $144-50$ and accompanying text.

179. Model Rules of Prof'L CONDUCt R. $3.8 \mathrm{cmt}$. (1997).

180. John D. Bessler, The Public Interest and the Unconstitutionality of Public Prosecutors, 47 ARK. L. REV. 511, 546 (1994) (quoting United States v. Young, 470 U.S. 1, 25 (1985) (Brennan, J., concurring in part and dissenting in part)).

181. The Supreme Court, and lower courts, long have held that the prosecutor is

the representative not of an ordinary party to a controversy, but of a sovereignty whose obligation to govern impartially is as compelling as its obligation to govern at all; and whose interest ... in a criminal prosecution is not that it shall win a case, but that justice shall be done.

Berger v. United States, 295 U.S. 78, 88 (1935); see also Stop Youth Addiction, Inc. v. Lucky Stores, Inc., 950 P.2d 1086, 1113 (Cal. 1998) (noting that California has taken an analogous view toward its own state prosecutors).
} 
dence was presented. ${ }^{182}$ "Due process jurisprudence developed by the Supreme Court in Brady v. Maryland also requires prosecutors to produce to defendants exculpatory evidence useful to impeach government witnesses." ${ }^{183}$ Moreover, the Supreme Court in Giglio held that Brady requires the prosecution to disclose the content of plea agreements forged with key witnesses. ${ }^{184}$ Courts consistently have held, however, that a prosecutor is not required to disclose evidence of a witness's rational expectation of leniency even if the prosecution is aware of it and the defense is not. ${ }^{185}$

The motivations to fabricate and self-exculpate are equally pervasive whether the testifying codefendant has a formal agreement or merely a rational expectation of leniency. ${ }^{186}$ Under the Model Rules of Professional Conduct, a prosecutor has the responsibility to ensure that loopholes in the system, or the prosecutor's use of his or her discretion, do not adversely affect the court's administration of justice and the procedural rights of the accused. ${ }^{187}$ Therefore, the gray area of informal plea agreements should be of considerable concern to prosecutors and courts. Prosecutors must realize that when they create rational expectations of leniency, their fundamental ethical duty to act as a "minister of justice" is implicated.

Prosecutors can resolve the problem posed by rational expectations of leniency in three ways: (1) stop using the testimony of codefendants; (2) create formal plea agreements with all testifying codefendants; or (3) create discoverable, admissible, and non-binding agreements that memorialize the codefendant's rational expectations of leniency and the fact that the witness may be granted leniency because of his or her testimony. The first choice is no choice at all. It ignores the realities of the justice system as it is administered. Codefendant testimony is often the only testimony directly implicating the accused, ${ }^{188}$ and, therefore, a system that did not allow prosecutors to

\footnotetext{
182. Miller v. Pate, 386 U.S. 1, 7 (1967).

183. Bessler, supra note 180, at 548 (citing Brady v. Maryland, 373 U.S. 83,87 (1963)).

184. See supra note 7.

185. See supra note 152 and accompanying text.

186. See supra Part IV.A.

187. Cf. supra note 179 and accompanying text.

188. See, e.g., People v. Hudson, 194 N.W.2d 329, 332 (Mich. 1972) (upholding the defendant's conviction of unarmed robbery based on testimony provided by others who had participated in the robbery).
} 
use this evidence would be inefficient and repugnant to justice. ${ }^{189}$ The second choice-requiring the prosecutor to strike a formal bargain with every testifying codefendant-would impinge severely on the prosecutor's executive function. ${ }^{190}$ The prosecutor should be allowed to "convince" codefendants to testify without a legislative or ethical mandate requiring that the codefendant benefit from providing incriminating testimony.

The third choice, however, recognizes the dangers posed by codefendant testimony and makes a justified and reasonable compromise between the executive function of the prosecution and the procedural rights of the accused. A discoverable, admissible, and nonbinding agreement between the prosecution and the testifying codefendant, memorializing the codefendant's rational expectations of leniency and the possibility of prosecutorial leniency, would substantially mitigate the prejudice posed by codefendant testimony elicited without a formal agreement. This document would give defense counsel the opportunity to zealously cross-examine the codefendant about his or her expectations, and the document would apprise the jury that this cross-examination is actually based on a rational and documented expectation of leniency and not simply on the codefendant's desire for repentance and absolution.

\section{B. Jury Instructions}

Courts and prosecutors should reconsider whether jury instructions are adequate to protect the defendant's right to a fair trial when a witness testifies against the defendant based on a rational expectation of leniency but without a formal plea agreement. Traditionally, courts have held that "mere expectations" of benefit are sufficiently exposed by properly instructing the jury. ${ }^{191}$ Courts in all federal circuits limit, or fail to give altogether, instructions on the potential haz-

189. See generally JAMES BOND, PleA BARGAINING AND GUILTY PleAs $§ 1.08$ (1975) (noting that a substantial number of codefendants and accomplices agree to give incriminating testimony in exchange for leniency).

190. See, e.g., Wayte v. United States, 470 U.S. 598, 607 (1985) (““'[T]he decision whether or not to prosecute, and what charge to file or bring before a grand jury, generally rests entirely in [the prosecutor's] discretion.") (quoting Bordenkircher v. Hayes, 434 U.S. 357, 364 (1978)); see also People v. Nelson, 238 N.W.2d 201, 203-04 (Mich. Ct. App. 1975) (“"For the judiciary to claim power to control the institution and conduct of prosecutions would be an intrusion on the power of the executive branch of government and a violation of the constitutional separation of powers."”) (quoting Genesee Prosecutor v. Genesee Circuit Judge, 194 N.W.2d 693, 699 (Mich. 1972)).

191. Hoffa v. United States, 385 U.S. 293, 311 (1966). 
ards of accomplice testimony motivated by "mere expectations." This is so even though overwhelming evidence suggests that the potential for malicious intent is just as pervasive whether a witness is motivated by a formal agreement or a rational expectation of leniency. ${ }^{193}$ Moreover, social science research indicates that individual jurors are incapable of properly weighing the credibility of witnesses testifying without a formal agreement.

Courts should make substantial changes to the jury instructions that accompany accomplice testimony, and scholars should make similar changes to pattern instructions. Although social science and common sense indicate that formal plea agreements and rational expectations of leniency create equal motivations to fabricate and selfexculpate, courts in a majority of the federal circuits use different jury instructions for codefendants who testify pursuant to a formal plea agreement and codefendants who testify based on a rational expectation of leniency. ${ }^{195}$ Courts should give a single pattern jury instruction that applies in both circumstances. This instruction should urge jurors to question the credibility of accomplice testimony in general, regardless of whether it is based on a formal agreement. The instruction suggested in Sand's Modern Federal Jury Instructions would certainly suffice:

[A]ccomplice testimony is of such nature that it must be scrutinized with great care and viewed with particular caution when you decide how much of that testimony to believe.

You should ask yourselves whether these so-called accomplices would benefit more by lying, or by telling the truth. Was their testimony made up in any way because they believed or hoped that they would somehow receive favorable treatment by testifying falsely? Or did they believe that their interests would be best served by testifying truthfully? If you believe that the witness was motivated by hopes of personal gain, was the motivation one which would cause him to lie, or was it one which would cause him to tell the truth? Did this motivation color his testimony?

192. See supra notes $164-71$ and accompanying text.

193. See supra notes $147-50$ and accompanying text.

194. See supra notes $172-78$ and accompanying text.

195. See supra notes $164-71$ and accompanying text. 
In sum, you should look at all of the evidence in deciding what credence and what weight, if any, you will want to give to the accomplice witnesses. ${ }^{196}$

This instruction likely would apprise a reasonable jury of an accomplice's various motivations to fabricate, lie, and cooperate with the prosecution. The instruction merely recognizes the truth about accomplice testimony.

\section{Cross-Examination}

Courts consistently limit the defense counsel's cross-examination of a witness about his or her expectations of leniency. ${ }^{197}$ For instance, in United States v. Page, ${ }^{198}$ the prosecutor impeached his own testifying codefendant by exposing the charges pending against the codefendant on direct examination. ${ }^{199}$ As a result, the trial court in Page did not permit defense counsel to thoroughly cross-examine the codefendant regarding the pending charges, because, according to the trial court, such cross-examination was redundant. ${ }^{200}$ Page was decided wrongly in the trial court and affirmed wrongly on appeal. As Justice O'Connor noted in Williamson v. United States, ${ }^{201}$ a codefendant who testifies without a grant of immunity or plea agreement waives his or her Fifth Amendment right against self-incrimination, and, as a result, is cloaked in a practically impenetrable veil of absolution and repentance. ${ }^{202}$ Consequently, Justice O'Connor noted, the credibility and weight of the codefendant's testimony is substantially bolstered because the jury is more likely to believe a defendant whose testimony is self-inculpatory and who "officially" has nothing to gain, and everything to lose, from testifying to the statements under oath. ${ }^{203}$ Thus, the prosecutor has a substantial interest in the "unencumbered" incriminating testimony of the codefendant. The codefendant's credibility is unjustifiably bolstered by the lack of a plea agreement, and

\footnotetext{
196. See 1 SAND ET AL., supra note 139, II 7.01, at 7-17 to 7-18.

197. See supra notes 157-60 and accompanying text.

198. Nos. 99-5361, 99-5449, 99-5451, 99-5456, 2000 U.S. App. LEXIS 31115 (6th Cir. Nov. 9, 2000).

199. Id. at *14-*17.

200. Id. at $* 17$.

201. 512 U.S. 594 (1994).

202. See supra note 16 and accompanying text.

203. See supra note 16 and accompanying text.
} 
the prosecutor's witness is protected by a judicial system that limits effective cross-examination.

Courts, therefore, should permit substantial, and sometimes redundant, cross-examination of codefendants who testify with expectations of leniency but without the obvious benefit of a formal plea bargain. For instance, defense counsel should be able to ask the codefendant whether the codefendant is aware that he is waiving his Fifth Amendment right against self-incrimination, whether the codefendant is aware of the penal consequences of this waiver, whether the codefendant has any expectation of leniency, and, if not, why the codefendant would want to expose himself or herself to such criminal liability with no hope of leniency or benefit. Moreover, defense counsel should be permitted to remind the codefendant of the laws and penalties relating to perjury and be permitted to explore this line of questioning such that the defendant's procedural rights are adequately protected.

\section{CONCLUSION}

Courts and academics have recognized the dangers posed by bargained-for testimony. ${ }^{204}$ The Supreme Court nevertheless has consistently held that the existent procedural safeguards are sufficiently stringent to protect the accused from any unfair prejudice created by bargained-for testimony. ${ }^{205}$ These safeguards fail to protect the rights of the accused where the witness's testimony is motivated not by a formal plea agreement but by an expectation of leniency. Witness testimony motivated by an expectation of leniency may implicate the policy concerns underlying Brady, may be unreliable under the Supreme Court's Confrontation Clause jurisprudence, and may pose ethical problems for prosecutors. These problems, however, can be mitigated if the judicial system makes three substantial yet unobtrusive changes to the current rules regulating accomplice testimony. By creating discoverable non-binding agreements between codefendants and prosecutors, giving stringent jury instructions, and allowing broad cross-examination, the prejudices posed to the accused by accomplice testimony, motivated by rational expectations of leniency, can be mitigated.

204. See supra Part II.

205. Again, for the purposes of this Note, this position is acceptable. See supra note 3. 